\title{
TINGKAT KEMATANGAN BIJI KOPI ARABICA (Coffea arabica L.) DALAM MENGHASILKAN KADAR KAFEIN
}

\author{
Srikandi*, Aprilia Widia Kristanti dan RTM Sutamihardja \\ Program Studi Biologi, Fakultas MIPA, Universitas Nusa Bangsa, \\ Jl. KH Sholeh Iskandar KM 4 Cimanggu Tanah Sereal, Bogor 16166 \\ *e-mail: sriuus@yahoo.co.id
}

\author{
ABSTRACT \\ Levels of Arabica (Coffea Arabica L.) Coffee Materials in Producing Caffein
}

\begin{abstract}
Coffee is a plantation crop that has long been cultivated in Indonesia. One type of coffee grown in Indonesia, namely arabica coffee. Arabica coffee is coffee that has superior quality compared to other types of coffee. Testing of caffeine content in Sukamakmur village arabica coffee is differentiated into three types of coffee berries based on the maturity level of the coffee fruit. The level of maturity of coffee fruit is marked by the color of coffee fruit skin. The collection of young coffee fruit is characterized by green fruit rind, half-aged coffee, orange rind and old coffee, dark red rind. Arabica coffee fruit is processed from drying, drying, and roasting and grinding into arabica ground coffee. Powder coffee samples are used for water content testing, phytochemical identification, and caffeine level testing. Caffeine content testing using UV-Vis spectrophotometry. The results of water content testing showed that the highest water content was found in coffee with a maturity level of half old, the lowest moisture content found in old coffee. Phytochemical identification testing performed showed powdered coffee samples containing active compounds of saponins, flavonoids, and alkaloids, as well as tannins. The highest caffeine content is found in ground coffee with the maturity level of coffee half old at $1.56 \%$ and the lowest caffeine level in ground coffee with a young coffee level of $0.93 \%$.
\end{abstract}

Keywords : Coffea arabica L., Level of maturity, Level of caffeine.

\begin{abstract}
ABSTRAK
Kopi adalah tanaman perkebunan yang sudah lama dibudidayakan di Indonesia. Salah satu jenis kopi yang ditanam di Indonesia, yaitu kopi arabika. Kopi arabika merupakan kopi yang memiliki kualitas superior dibanding jenis kopi lainnya. Pengujian kadar kafein pada kopi arabika desa Sukamakmur dibedakan menjadi tiga jenis pengambilan buah kopi berdasarkan tingkat kematangan buah kopi. Tingkat kematangan buah kopi ditandai dengan warna kulit buah kopi. Pengambilan buah kopi muda ditandai dengan kulit buah berwarna hijau, kopi setengah tua, kulit buah berwarna jingga dan kopi tua, kulit buah berwarna merah tua. Buah kopi arabika diolah dari penjemuran, pengeringan, dan penyangraian serta penggilingan menjadi kopi bubuk arabika. Sampel kopi bubuk digunakan untuk bahan pengujian kadar air, identifikasi fitokimia dan pengujian kadar kafein. Pengujian kadar kafein menggunakan metode spektrofometri UV-Vis. Hasil pegujian kadar air menunjukkan bahwa kadar air tertinggi terdapat pada kopi dengan tingkat kematangan setengah tua, kadar air terendah terdapat pada kopi tua. Pengujian identifikasi fitokimia yang dilakukan menunjukan sampel kopi bubuk mengandung senyawa aktif saponin, flavonoid, dan alkaloid, serta tanin. Kadar kafein tertinggi terdapat pada kopi bubuk dengan tingkat kematangan kopi setengah tua sebesar 1,56\% dan kadar kafein terendah pada kopi bubuk dengan tingkat kopi muda sebesar $0,93 \%$.
\end{abstract}

Kata kunci: Coffea arabica L., Tingkat kematangan, Kadar kafein.

\section{PENDAHULUAN}

Kopi merupakan tanaman perkebunan yang sudah lama menjadi tanaman yang dibudidayakan. Tanaman kopi menjadi sumber penghasilan rakyat dan juga meningkatkan devisa negara lewat ekspor biji mentah maupun olahan dari biji kopi. International Coffee Organizationdalam
Budiman (2012) mengatakan bahwa Indonesia dinilai cukup strategis di dunia perkopian internasional, karena Indonesia merupakan negara pengeskpor terbesar ketiga setelah Brazil dan Vietnam.Jenis-jenis kopi yang ditanam di Indonesia pada saat ini terdiri dari tiga jenis kopi, yaitu kopi robusta, arabika dan liberika (Johnstonet al.,2003). Kopi arabika (Coffea arabicaL.) adalah kopi 
yang paling baik mutu cita rasanya dibanding jenis kopi yang lain dengan cita rasa khas kopi arabika yang kuat dan rasa sedikit asam. Kafein merupakan metabolit sekunder dalam biji kopi, dan termasuk senyawa alkaloid derivat xantin yang mengandung gugus metil (Sunaryo, 2005).

Kadar kafein pada tanaman kopi arabika dipengaruhi beberapa faktor, yaitu faktor gen kopi dan lingkungan. Faktor lingkungan anatara lain kandungan hara, waktu panen, dan kondisi tanah tempat tumbuh (Abdullah et al., 2010). Waktu panen merupakan salah satu faktor lingkungan yang memberikan pengaruh terhadap kadar senyawa dalam tubuh tumbuhan. Waktu panen kaitannya sangat erat dengan tingkat kematangan buah. Tingkat kematangan pada buah biasanya ditandai dari warna kulit buah. Perubahan warna kulit buah yang terjadi menunjukkan bahwa telah terjadi perubahan susunan kimia yang terkandung di dalam buah tersebut. Kopi arabika juga termasuk dalam tanaman buah yang memiliki waktu panen dan tingkat kematangan dalam waktu tertentu. Kopi arabika biasanya berwarna hijau saat muda, agak kekuningan sampai kemerahan saat setengah tua dan merah terang sampai merah gelap saat sudah tua (Abdullah et al., 2010). Tingkat kematangan buah kopi arabika mempengaruhi kandungan senyawa kimia dalam biji kopi, terutama kafein. Kadar kafein dalam biji kopi berbeda tergantung pada tingkat kematangan saat buah kopi dipanen. Penelitian ini dilakukan untuk mengetahui pengaruh perbedaan tingkat kematangan buah kopi arabika dari desa Sukamakmur terhadap kadar kafein yang dikandungnya.

\section{BAHAN DAN METODE}

\section{Bahan dan Alat}

Bahan-bahan yang digunakan adalah aluminium foil, akuades, amil alkohol, amonia $\left(\mathrm{NH}_{4} \mathrm{OH}\right)$, asam klorida ( $\mathrm{HCl}$ pekat), asam sulfat $\left(\mathrm{H}_{2} \mathrm{SO}_{4}\right.$ pekat), feri klorida $\left(\mathrm{FeCl}_{3}\right)$, hidrogen peroksida $\left(\mathrm{H}_{2} \mathrm{O}_{2}\right)$, indikator pp, kalsium karbonat $\left(\mathrm{CaCO}_{3}\right)$, kapas, kloroform $\left(\mathrm{CHCl}_{3}\right)$,natrium hidroksida $(\mathrm{NaOH})$, pereaksi mayer, pereaksi wagner, pereaksi dragendorff, kopi arabika varietas
Sigarar yang berasal dari Desa Sukamakmur, Kabupaten Bogor, serbuk magnesium, dan standar kafein.Alat-alat yang digunakan adalah autoklaf, cawan porselen, desikator, oven, hotplate (Wisestir), kertas saring, sudip, wajan, propan-werke, neraca analitik (Ohaus), water bath, mesin penggiling biji kopi, penyaring ukuran 60 mesh, plat tetes, peralatan gelas, rotary evaporator, spektrofotometer UV (Optizen).

\section{Metode}

Tahapan metode penelitian antara lain preparasi sampel, skrining fitokimia, danpenentuan kadar air,serta penentuan kadar kafein.

\section{Preparasi sampel}

Buah kopi arabika yang berasal dari Desa Sukamakmur, Kabupaten Bogor dengan tingkat kematangan yang berbeda (kopi muda berumur 2 bulan, kopi setengah tua berumur 4 bulan dan kopi tua berumur 7 bulan) dijemur di bawah sinar matahari sampai kering, dipisahkan antara biji kopi dengan kulitnya, bijinya disangrai dengan wajan pada suhu $190^{\circ} \mathrm{C}$ selama 30 menit. Sampel digiling dengan mesin penggiling biji kopi hingga menjadi kopi bubuk. Kopi bubuk disaring dengan penyaring ukuran 60 mesh.

\section{Penentuan Kadar Air (SNI 01-2891- 1992)}

Sampel bubuk kopi arabika ditimbang sebanyak 1-2 gram pada cawan porselen yang telah dikeringkan dan diketahui bobot kosongnya, kemudian sampel dimasukkan ke dalam oven selama 3 jam dengan suhu 105 ${ }^{\circ} \mathrm{C}$. Setelah 3 jam, sampel kemudian disimpan di dalam desikator selama 15 menit dan ditimbang kembali untuk mengetahui bobot setelah pemanasan.

\section{Uji Fitokimia (Harborne, 1987)}

a. Uji Saponin (uji busa)

Sejumlah ekstrak kopi bubuk dimasukkan dalam tabung reaksi yang kemudian dipanaskan pada penangas air. Reaksi positif ditunjukkan dengan terbentuknya busa yang stabil selama 5 menit dan tidak hilang pada penambahan 1 tetes $\mathrm{HCl} 2 \mathrm{~N}$. 


\section{b. Uji Flavonoid}

Sejumlah ekstrak sampel kopi bubuk ditambahkan serbuk magnesium $0,1 \mathrm{mg}$, $0,4 \mathrm{~mL}$ amil alkohol dan $4 \mathrm{~mL}$ alkohol kemudian campuran dikocok. Reaksi positif ditunjukkan dengan terbentuknya warna merah, kuning atau jingga pada lapisan amil alkohol.

c. Uji Alkaloid

Sejumlah sampel kopi bubuk dimasukkan ke dalam gelas piala yang kemudian ditambahkan dengan $10 \mathrm{~mL}$ kloroform dan $\mathrm{NH}_{4} \mathrm{OH}$ pekat sampai suasana basa. Campuran tersebut kemudian disaring dan filtratnya ditambahkan dengan $\mathrm{H}_{2} \mathrm{SO}_{4} 2 \mathrm{~N}$. Larutan tersebut kemudian dikocok hingga terbentuk dua lapisan. Lapisan asam (tidak berwarna) dimasukkan ke dalam tiga bagian plat tetes dan ditambahkan dengan pereaksi Mayer pada bagian pertama, pereaksi Wagner pada bagian kedua, serta pereaksi Dragendorf pada bagian ketiga. Reaksi positif ditunjukkan dengan terbentuknya endapan putih kekuningan pada penambahan pereaksi Mayer, endapan cokelat pada penambahan pereaksi Wagner, dan endapan jingga pada penambahan pereaksi Dragendorf.

d. Uji Tanin

Sejumlah ekstrak kopi bubuk dimasukkan ke dalam tabung reaksi yang kemudian ditambahkan dengan $\mathrm{FeCl}_{3} 1 \%$. Reaksi positif ditunjukkan dengan terbentuknya warna hijau, biru, atau hitam pada larutan.

\section{Kadar Kafein (Fitri, 2008)}

a. Pembuatan Larutan Standar Kafein Standar kafein sebanyak $100 \mathrm{mg}$ dimasukkan ke dalam labu ukur $1000 \mathrm{~mL}$ dan ditepatkan hingga tanda batas dengan akuades (100 ppm). Larutan standar tersebut kemudian dipipet sebanyak 0 ; 0,$25 ; 0,5 ; 1 ; 2 ; 3 ; 4 ; 5 ; 7,5 ; 10 \mathrm{~mL}$ ke dalam labu takar $50 \mathrm{~mL}$ dan ditepatkan hingga tanda batas dengan akuades untuk mendapatkan konsentrasi larutan standar sebesar $0 ; 0,5 ; 1 ; 2 ; 4 ; 6 ; 8 ; 10 ; 15 ; 20$ $\mathrm{mg} / \mathrm{L}$. Larutan standar tersebut diukur dengan spektrofotometer UV pada panjang gelombang maksimum $(250-300 \mathrm{~nm})$ dan kemudian dibuat kurva kalibrasi hubungan antara absorbansi dengan konsentrasi larutan standar.

b. Penentuan Panjang Gelombang Maksimum Kafein

Larutan standar kafein sebanyak 4 $\mathrm{mL}$ dengan konsentrasi 100 ppm dipipet, dimasukkan ke dalam labu ukur $50 \mathrm{~mL}$, diencerkan dengan akuades hingga garis tanda dan dihomogenkan. Larutan standar yang diukur absorbansinya dengan spektrofotometer UV pada panjang gelombang $250-300 \mathrm{~nm}$. Sebagai uji blanko digunakan akuades.

c. Ekstraksi Kafein

Sebanyak 1 g kopi bubuk dimasukkan ke dalam gelas piala, ditambahkan $150 \mathrm{~mL}$ air panas dan diaduk selama 2 menit. Larutan kopi disaring melalui corong dengan kertas saring ke dalam erlenmeyer. Serbuk $\mathrm{CaCO}_{3}$ sebanyak 1,5 gram dan larutan kopi dan dimasukkan ke dalam corong pisah lalu diekstraksi sebanyak 4 kali, masingmasing dengan penambahan $25 \mathrm{~mL}$ kloroform. Lapisan atas (fraksi kloforom) diambil, diuapkan dengan water bath hingga membentuk ekstrak kering. Ekstrak kering tersebut dimasukkan ke dalam labu ukur $100 \mathrm{~mL}$ dan diencerkan dengan akuades hingga $100 \mathrm{~mL}$. Larutan sampel diukur absorbansi pada panjang gelombang maksimum (250-300 nm). Perhitungan kadar kafein pada kopi bubuk adalah sebagai berikut:

$$
\% \mathrm{~b} / \mathrm{b}=
$$

$\frac{\text { konsentrasi }\left(\frac{\mathrm{mg}}{\mathrm{L}}\right) \times \text { volume sampel }(\mathrm{L}) \times \mathrm{fp}}{\text { mg sampel }} \times 100$

\section{HASIL DAN PEMBAHASAN}

\section{Rendemen Kopi Bubuk}

Sampel kopi yang digunakan adalah kopi arabika varietas Sigarar utang yang dipetik dari kebun kopi desa Sukamakmur. Tanaman kopi berumur 4 tahun dan sampel kopi yang digunakan adalah berdasarkan tingkat kematangan yang dapat dilihat dari warna kulit buah kopi serta umur buah kopi.Kopi muda berumur 2 bulan adalah kopi yang memiliki kulit buah berwarna hijau tua, daging buahnya masih keras, kopi setengah tua berumur 4 bulan kulitnya berwarna 
kuning sampai jingga, daging buah agak lunak dan kopi tua berumur 7 bulan berwarna merah terang sampai merah tua, daging buah lunak dan berair. Tingkat kematangan buah kopi dapat dilihat pada Gambar 1.

Kopidiolah secara kering, kopi muda dan tua langsung dijemur bersama kulitnyasedangkan untuk kopi tua dikupas kulitnya terlebih dahulu setelah itu dijemur di bawah sinar matahari selama 14 hari. Massa masing-masing kopi sebelum dijemur sekitar 2 kilogram. Pengolahan kopi selanjutnya disangrai dan digiling menjadi bubuk kopi, dalam proses ini massa kopi mengalami penurunan. Penurunan massa kopi ini berhubungan dengan nilai rendemen (Gambar 2.)

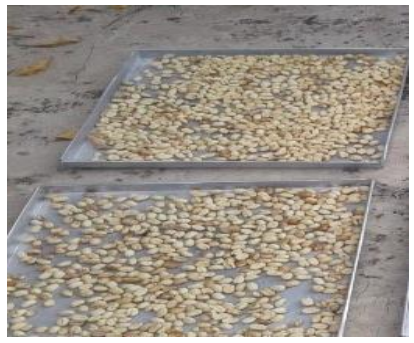

(a)

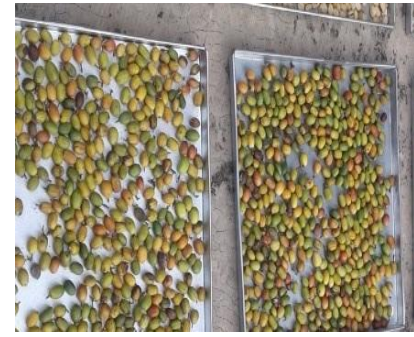

(b)

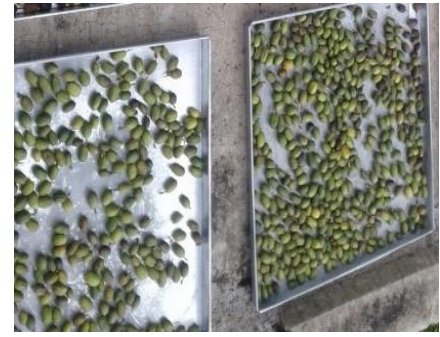

(c)

Gambar 1. Tingkat Kematang Buah Kopi Arabika(a) Kopi Tua, (b) Kopi Setengah Tua, (c) Kopi Muda

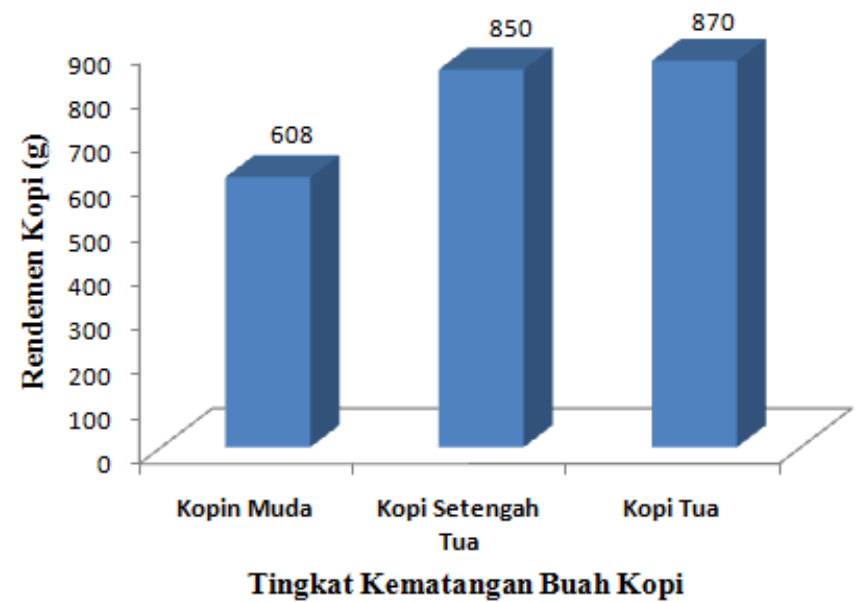

Gambar 2. Nilai Rendemen Kopi

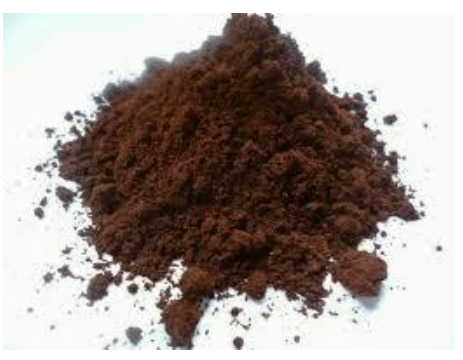

(a)

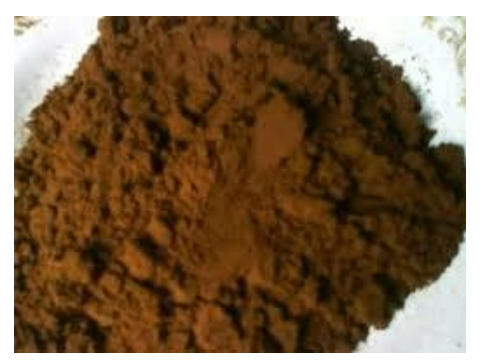

(b)

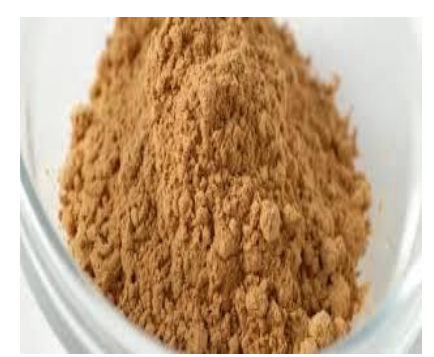

(c)

Gambar 3. Bubuk Kopi Berdasarkan Tingkat Kematangan Buah Kopi, (a) Kopi Tua, (b) Kopi Setengah Tua(c) Kopi Muda 
Rendemen kopi arabika adalah perbandingan massa kopi arabika yang setelah proses dibanding dengan massa kopi sebelum diproses dengan menggunakan satuan persen. Kopi muda memiliki nilai rendamen $0,30 \%$, kopi setengah tua $0,42 \%$ dan kopi tua $0,43 \%$. Semakin tinggi nilai rendemen maka kopi bubuk yang di hasilkan semakin banyak. Bubuk kopi berdasarkan tingkat kematangan buah kopi dapat dilihat pada Gambar 3.

\section{Uji Fitokimia}

Hasil penelitian yang diperoleh menunjukkan bahwa kopi mengandung metabolit sekunder berupa alkaloid, flavonoid, tanin dan saponin yang ditandai dengan terbentuknya hasil positif dari reaksi antara sampel dengan pereaksi yang digunakan pada identifikasi fitokimia. Kopi arabika dari desa Sukamakmur mengandung alkaloid, tanin, saponin dan flavonoid hasil uji dapat dilihat pada Tabel 1 .

\section{Kadar Air}

Kadar air tertinggi terdapat pada kopi setengah tua, dikarenakan dalam proses pengolahannya biji kopi masih bercampur dengan daging buah kopi, yang terjadi pada saat penjemuran buah kopi arabika. Buah kopi setengah tua dijemur dibawah sinar matahari bersama daging buah dikarenakan sulitnya melakukan pengupasan kulit buah dari biji kopi. Hal ini membuat kadar air dalam biji bertambah karena, buah yang setengah masak memiliki kadar air sekitar $65 \%$ dan berpengaruh memberikan efek kelembapan pada biji kopi (Lee, 2002). Apabila sirkulasi udara tidak lancar maka akan menjenuhkan atmosfer pada permukaan kopi, sehingga kopi mudah menyerap uap air yang ada di udara yang mengakibatkan kadar air dari kopi dapat meningkat (Twishsri et al., 2006). Kadar air dapat dilihat pada Gambar 4.

Tabel 1. Hasil Identifikasi Fitokimia

\begin{tabular}{|c|c|c|c|c|c|c|c|}
\hline \multirow{3}{*}{ No. } & \multirow{3}{*}{ Nama Sampel } & \multicolumn{5}{|c|}{ Parameter } & \multirow{3}{*}{ Saponin } \\
\hline & & \multicolumn{3}{|c|}{ Alkaloid } & \multirow[t]{2}{*}{ Flavonoid } & \multirow[t]{2}{*}{ Tanin } & \\
\hline & & Mayer & Wagner & Dragondorf & & & \\
\hline 1 & Kopi muda & ++ & ++ & +++ & +++ & +++ & + \\
\hline 2 & $\begin{array}{l}\text { Kopi setengah } \\
\text { tua }\end{array}$ & +++ & ++ & ++ & +++ & +++ & +++ \\
\hline 3 & Kopi tua & +++ & +++ & +++ & ++ & +++ & + \\
\hline $\begin{array}{c}\text { Kete } \\
++ \\
++ \\
+\end{array}$ & $\begin{array}{l}\text { angan : } \\
\quad=\text { Sangat pek } \\
\quad=\text { Pekat } \\
\quad=\text { Kurang pel }\end{array}$ & & & & & & \\
\hline
\end{tabular}

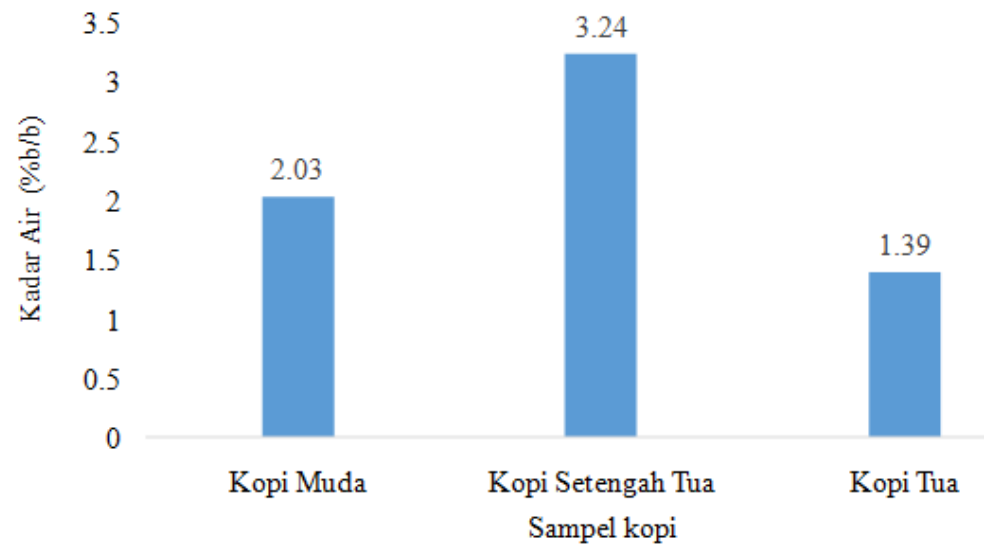

Gambar 4. Grafik Kadar Air 


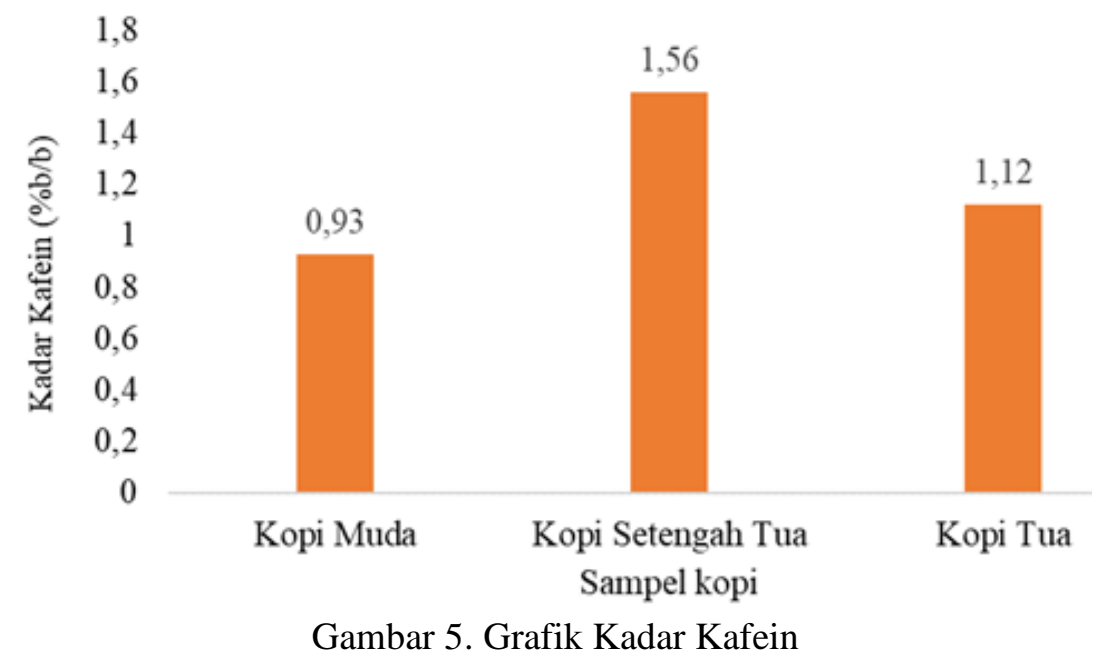

Kadar air terendah terdapat pada kopi tua, dikarenakan kopi yang sudah tua kulit buahnya mudah dikupas sehingga pada saat penjemuran tidak bersama dengan daging buah, mengakibatkan biji kopi lebih cepat kering dan biji kopi masih terbungkus kulit tanduk (hard skin). Kulit tanduk berperan sebagai penghambat keluar masuknya air dari dalam biji (Lee, 2002).

\section{Kadar Kafein}

Penentuan kadar kafein dalam kopi arabika bubuk adalah dengan cara mengekstraksi kopi. Pada proses ekstraksi, air dipanaskan hingga $95{ }^{\circ} \mathrm{C}$ agar dapat melarutkan komponen-komponen yang terdapat dalam kopi. Pemanasan membuat air memuai dan ikatan antar molekulnya menjadi longgar sehingga dapat melarutkan komponen kopi (Andarwulan et al., 2011). Hasil analisis kadar kafein dapat dilihat pada Gambar 5.

Kadar kafein tertinggi dari hasil analisis terdapat pada kopi dengan tingkat kematangan setengah tua/pada kopi yang berwarna kuning sampai jingga. Kopi setengah tua merupakan kopi yang memiliki kandungan metabolit sekundernya yang tinggi dikarenakan kopi setengah tua sedang mengalami perkembangan pembentukan metabolit sekunder yang pesat dengan kondisi biji kopi yang cukup baik, terlihat dari bentuk bagian kopi yang sempurna, yang utuh dan relatif ukurannya cukup besar sehingga dapat terjadi pembentukan metabolit yang optimum. Sedangkan pada buah kopi muda, memiliki kadar kafein rendah dikarenakan pembentukan bagian biji kopi belum sempurna dan untuk buah kopi yang tua ketika kopi masak akan mengalami penurunan senyawa metabolit karena proses biokimiawi di dalam biji mulai melambat, sehingga proses pembentukan metabolit tidak optimum (Rukmana, 1999).

\section{KESIMPULAN}

Kadar kafein tertinggi kopi arabika terdapat pada tingkat kematangan kopi setengah tua yang berwarna jingga.

\section{DAFTAR PUSTAKA}

Abdullah. (2010). Thermogravimetry Study on Pyrolysis of Various Lignocellulosic Biomass for Potential Hydrogen Production. IJCBS.

Andarwulan N., Kusnandar F., Herawati D., (2011). Analisis Pangan. Jakarta: Dian Rakyat Jakarta

Budiman, H. (2012). Prospek Tinggi Bertanam Kopi. Yogyakarta: Pustaka. Baru Press.

Harborne, J.B. (1987). Metode Fitokimia Penuntun Cara Modern Menganalisis Tumbuhan. Penerbit ITB. Bandung.

Johnston, K.L., Clifford, M.N., Morgan, L.M. (2003). Coffee Acutely Modifies 
Gastrointestinal Hormone Secretion and Glucose Tolerance in Humans: Glycemic Effects of Chlorogenic Acid and Caffeine, Am J Clin Nutr.

Lee, C. (2002). Green coffee storage: A factor that ought not to be overlooked from tea \& coffee trade. Journal Feb 1999. Sweet Maria Com.

Rukmana, R. (1999). Bertanam Buah-buahan di Pekarangan. Kanisius Yogyakarta.
Standar Nasional Indonesia. 1992. Kopi Instan No. SNI 01-2983-1992

Sunaryo, R. (2005). Perangsangan susunan saraf pusat. Dalam: Farmakologi dan terapi FKUI. Jakarta.

Twishsri, W., Chapman, K., Marsh, A., Frank, J.M., Kraitong, T., Kasinkasaempong, $\quad$ Y., Kosicharoenkul, S., and Nopchinwong, P. (2006). Thailand Coffee Bag Linier Storage Trial. FAO-DOA Special R\&D Report on the FAO-Thailand Robusta Coffee Project. Thailand. 